\title{
ROOTING OF GUANANDI (Calophyllum brasiliense CAMBESS) CUTTINGS USING INDOLE-BUTYRIC ACID
}

Keywords:

Improvement programs Adventitious roots

Vegetative propagation

Histórico:

Recebido 10/12/2013

Aceito 23/1 I/2015

Palavras chave:

Programas de melhoramento Raízes

Propagação vegetativa

Correspondência: eduardo@tropicalflora.com.br
ABSTRACT: Commercial reforestation of Brazilian native species to produce hardwood for sawmills has been recently intensified in the country. Among the potential species planted by the logging industry is guanandi (Calophyllum brasiliense Cambess) because it is widely distributed in the country, highly adapted to different soil and climate conditions, good bole form and high quality timber. The development of genetic improvement programs should prioritize gains in productivity and yields in the medium and long term. For such programs to be successful, the study of vegetative propagation techniques to abbreviate steps in forest improvement and allow its mass production is fundamental. To assess the viability of vegetative propagation of the species, two successive experiments were carried out during two years testing the best type of cutting, hormone concentration and management. Different cuttings types submitted to increasing doses of indole-butyric acid (IBA) were tested to evaluate survival, sprouting, rooting and callus formation. Results indicate that the species is viable for vegetative propagation with 85 to $90 \%$ rooting of cuttings from seedlings in the IBA concentrations of 3000 to $7000 \mathrm{mg} \cdot \mathrm{L}^{-1}$. For the cuttings, sprouting from the base of adult trees $3000 \mathrm{mg} \cdot \mathrm{L}^{-1}$ was the best concentration of IBA.

\section{ENRAIZAMENTO DE ESTACAS DE GUANANDI (Calophyllum brasiliense CAMBESS) UTILIZANDO O ÁCIDO INDOL-BUTÍRICO}

RESUMO: O reflorestamento comercial de espécies nativas brasileiras, visando à produção de madeira nobre para serraria, tem se intensificado nos últimos anos em diversas regiões do Brasil. Dentre as espécies nativas potenciais que veem sendo plantadas por empresas do setor florestal, o guanandi (Calophyllum brasiliense Cambess.) é destaque, uma espécie com ampla distribuição natural, alta adaptabilidade a diferentes condições de solo e clima, boa forma fuste e ótima qualidade madeira. $O$ desenvolvimento de um bom programa de melhoramento genético requer prioridade para a obtenção de ganhos de produtividade e rendimento no médio e longo prazo. Nesta linha de pesquisa, o estudo das técnicas de propagação vegetativa, visando abreviar etapas no melhoramento florestal e viabilizar a produção maciça de material melhorado, tem importância fundamental no sucesso do programa de melhoramento. Com objetivo de avaliar a viabilidade da propagação vegetativa da espécie, foram realizados dois experimentos sucessivos, instalados e avaliados ao longo de dois anos, a fim de identificar os melhores tipos de estacas, doses de hormônio e manejo. Foram testados diferentes tipos de estacas, submetidas a doses crescentes de ácido indolbutírico (AIB), avaliados principalmente os dados de sobrevivência, emissão de brotos e formação de raiz. Os resultados indicaram que a espécie se mostrou viável a propagação vegetativa, obtendo índices de $85 \%$ a $90 \%$ de enraizamento de estacas provenientes de mudas, para as doses de ácido indolbutírico (AIB) nas concentrações entre 3.000 a $7.000 \mathrm{mg} \cdot \mathrm{L}^{-1}$. Para as estacas de brotações da base de árvores adultas 3.000 $\mathrm{mg} \cdot \mathrm{L}^{-1}$ foi a melhor dose de AIB. 


\section{INTRODUCTION}

In Brazil, forestry is an activity with economic and social importance due to the production of a wide variety of commercial products such as resins, essential oils, fruits and honey (CARPANEZZI, 2000), and mainly paper, cellulose, timber, hardboard, veneer, plywood, and particle board (TZFIRA et al., 1998; MORA \& GARCIA, 2000). Such products play important roles in the life quality of people, directly and indirectly, by generating more than two million jobs (FERREIRA \& GALVÃO, 2000).

According to the Brazilian Association of the Mechanically Processed Wood Industry- $\mathrm{ABIMCl}(2008)$, plantation forests covered 5.98 million ha in 2007, of which $62.7 \%$ were eucalyptus, $30.2 \%$ pine, and $7.1 \%$ other species such as acacia, rubber trees, paricá, and teak, among others. The development of the industry was focused on the production of exotic species, which corresponded to $97 \%$ of the area planted in the country in 2007 and only $3 \%$ with commercial plantation of native species.

Interest in the production of hardwood with high aggregated value has grown in the last decade in Brazil, especially for the plantation of teak (Tectona grandis), Australian cedar (Toona cilliata), and African mahogany (Khaya sp.) among the exotic species, and guanandi (Calophyllum brasiliense Cambess) and mahogany (Swietenia macrophylla) in the native species group.

Calophyllum brasiliense was used in the present study because it is a native species known worldwide for timber quality, widely distributed in the tropical region, and commercially planted in Latin America with good growth results in experimental plots (PIOTTO et al., 2003a; PIOTTO et al., 2003b). The vegetative propagation of this species is being studied and comproved by Santos et al (2010) and Kalil Filho et al (2010), presenting good rooting results.

The economic uses of vegetative propagation for seedling production in the forestry sector is justified when it has availability of high productive genotypes and, or, the seed is a limited resource (Xavier et al. 2003). For Calophyllum brasiliense, seeds are not a limitation for commercial seedling production, since many commercial plantations are producing seeds in quantity, regularly and with high quality. In this study, the focus was to develop the vegetative propagation technics for Calophyllum brasiliense, to produce clonal seedling of high productive genotypes.

\section{MATERIAL AND METHODS}

The study was part of the Calophyllum brasiliense Genetic Improvement Program of the Tropical Flora Reforestation Company in partnership with the Faculty of Agrarian Sciences (FCA/UNESP), Botucatu campus, Department of Plant Production and the graduate program in Forestry.

The study included two rooting trials between 2007 and 2009 in the greenhouse of the Plant Production Department, FCA/UNESP. The cuttings used in the study were produced in the nursery and in the commercial plantation sites of Tropical Flora Reforestation Company, in the city of Garça, SP.

Different concentrations of indole-butyric acid (IBA) were tested to identify the most adequate concentration for the species. Other parameters assessed were the provenance of the cuttings (from seedlings or from different parts of the tree top, crown or base), either lignified or young.

Materials used in the experiments, such as cartridges, trays and substrates were provided by the nursery from the Department of Natural Resources, FCA/UNESP. The same commercial substrate was used for all rooting trials, and it was composed by pine bark, vermiculite, acidity corrector, and mineral fertilizers with a cation exchange capacity of $200 \mathrm{mmol} \mathrm{c} \cdot \mathrm{kg}^{-1}$.

\section{First rooting trial}

In the first rooting trial (Table I) several possibilities were tested to find a direction for the following trials. Thus, different types of cuttings from trees were used to test rooting of mature material, cuttings $10 \mathrm{~cm}$ long were collected from three positions on the trees: base ( 0 to $50 \mathrm{~cm}$ height), crown ( 0.5 to $2.0 \mathrm{~m}$ height), top (>3.0 m height), and divided in two groups, lignified and young. The trees that provided the material for the first trial came from a productive plot of Tropical Flora, in Garça/SP, with four years of age, of mixed provenances, with good nutrition conditions and free of pests or diseases. In all types of cuttings, five doses of IBA were tested, including a control: 0, 100, 1000,5000 and $10000 \mathrm{mg} \cdot \mathrm{L}^{-1}$. Cuttings were planted in polyethylene cartridges of $45 \mathrm{~mm}$ diameter and 68$\mathrm{cm}^{3}$ volume. The cuttings were removed from the plastic tubes to assess rooting and callus growth. The test included 30 treatments, in triplicate, with 4 cuttings per treatment, starting on September 19, 2007, and assessed on January 20, 2008. 
Table I Description of treatments ( I to 30), portion of the tree from where the cuttings was collected (tree base, crown, top), types of cuttings (lignified or young) and the concentration of IBA used (0, 100, 1000, 5000 and $\left.10000 \mathrm{mg} \cdot \mathrm{L}^{-1}\right)$, with Calophyllum brasiliense.

Tabela I Descrição do tratamentos (I a 30), proporção de árvores onde foram coletadas os brotos (base da árvore, copa, topo), tipo de brotos (lignificado ou jovem) e a concentração de AIB usado (0,100, 5000 e $\left.10000 \mathrm{mg} \cdot \mathrm{L}^{-1}\right)$, em Calophyllum brasiliense.

\begin{tabular}{|c|c|c|c|c|c|c|c|}
\hline \multicolumn{8}{|c|}{$I^{\circ}$ Rooting trial / GUANANDI - Date : $19 / 09 / 2007$} \\
\hline Treatments & Portion & Type & Dose (AIB) ppm & Treatments & Portion & Type & Dose (AIB) ppm \\
\hline I & Top & Lignified & 0 & 16 & Crown & Young & 0 \\
\hline 2 & Top & Lignified & 100 & 17 & Crown & Young & 100 \\
\hline 3 & Top & Lignified & 1000 & 18 & Crown & Young & 1000 \\
\hline 4 & Top & Lignified & 5000 & 19 & Crown & Young & 5000 \\
\hline 5 & Top & Lignified & 10000 & 20 & Crown & Young & 10000 \\
\hline 6 & Top & Young & 0 & 21 & Tree base & Lignified & 0 \\
\hline 7 & Top & Young & 100 & 22 & Tree base & Lignified & 100 \\
\hline 8 & Top & Young & 1000 & 23 & Tree base & Lignified & 1000 \\
\hline 9 & Top & Young & 5000 & 24 & Tree base & Lignified & 5000 \\
\hline 10 & Top & Young & 10000 & 25 & Tree base & Lignified & 10000 \\
\hline 11 & Crown & Lignified & 0 & 26 & Tree base & Young & 0 \\
\hline 12 & Crown & Lignified & 100 & 27 & Tree base & Young & 100 \\
\hline 13 & Crown & Lignified & 1000 & 28 & Tree base & Young & 1000 \\
\hline 14 & Crown & Lignified & 5000 & 29 & Tree base & Young & 5000 \\
\hline 15 & Crown & Lignified & 10000 & 30 & Tree base & Young & 10000 \\
\hline
\end{tabular}

\section{Second rooting trial}

In the second rooting trial (Table 2), was tested cuttings from the tree base and cuttings from seedlings was included. Two more doses of IBA were added, with a total seven doses, including control treatment. Six-months cuttings originated from the same seed batch from nursery was used ( $40 \mathrm{~cm}$ height, good health and ready for planting).

\section{Statistics analyses}

For the statistical analysis, data from the first trial were $(X+0.5)^{-2}$ transformed to fulfill the assumption of data normality and also to maintain coefficient of variation within limits to perform analysis of variance (ANOVA). No data transformation was required for the results from the second trial. Mean values of survival, rooting, sprouting and callus growth were compared with Tukey test at $5 \%$ probability (PIMENTEL-GOMES, 1978) using the statistic software Sisvar (FERREIRA, 2003) for the first and second rooting trials.

\section{RESULTS AND DISCUSSION}

\section{First rooting trial}

Survival, rooting, sprouting and callus growth were assessed I 20 days after the implementation of the trial. Mean survival of the treatments was of $60.2 \%$, and mortality was mainly from fungi attack on the cuttings, probably caused by
Table 2 Second rooting trial with Calophyllum brasiliense. Treatments (I to I4), position of the cuttings (from the tree base or seedlings top), type of cutting (tree or seedlings) and doses of IBA (0, 100, 1000, 3000, 5000, 7000 and $\left.10000 \mathrm{mg} \cdot \mathrm{L}^{-1}\right)$.

Tabela 2 Segundo teste de enraizamento com Calophyllum brasiliense. Tratamentos ( I a |4), posição dos brotos (base árvore ou topa da muda), tipo de broto (árvore ou muda) e doses de AIB (0, 100, 1000, 3000, 5000, 7000 and $\left.10000 \mathrm{mg} \cdot \mathrm{L}^{-1}\right)$.

\begin{tabular}{cccc}
\hline \multicolumn{3}{c}{ 2 $^{\text {nd }}$ ROOTING TRIAL / GUANANDI - DATE : 0I/03/2009 } \\
\hline Treatments & Portion & Type & Dose (IBA) ppm \\
\hline I & Tree Base & Tree & 0 \\
3 & Tree Base & Tree & 100 \\
4 & Tree Base & Tree & 1000 \\
5 & Tree Base & Tree & 3000 \\
6 & Tree Base & Tree & 5000 \\
7 & Tree Base & Tree & 7000 \\
8 & Tree Base & Tree & 10000 \\
9 & Seedling Top & Seedling & 0 \\
10 & Seedling Top & Seedling & 100 \\
II & Seedling Top & Seedling & 1000 \\
12 & Seedling Top & Seedling & 3000 \\
13 & Seedling Top & Seedling & 5000 \\
I4 & Seedling Top & Seedling & 7000 \\
\hline
\end{tabular}


the long period inside the greenhouse and/or by the humidity excess throughout the I 20 days of experiment. No fungicide was applied during the experiment.

Table 3 presents the results for survival rate, rooting, sprouting, and callus growth of the first trial. The best results both for young and lignified cuttings were from the tree bases (treatments 21 to 30 ).

Results from the analysis of variance (ANOVA) and Tukey test at 5\% probability are presented in Table 4. No significant differences for survival, sprouting and callus growth were observed, whereas for rooting there was significant differences in treatments 18, 23, 25, 27, 28 and 29 , all from cuttings from the tree base, except treatment 18. The best performance was with treatment 28 , with $83.3 \%$ rooting and $100 \%$ survival (Table 4 ). The coefficient of variation for rooting, the main objective of the present study, was $18.17 \%$, below the desirable $20 \%$ limit.

Comparing the three portions (top, crown, base) of the trees from where the cuttings were taken, those from the base of the trees $(0$ to $50 \mathrm{~cm})$ resulted in

Table 3 Percentage of survival, rooting, sprouting and callus growth (treatments I to 30) with the five doses of indole-butyric acid (IBA) tested $(0,100,1000,5000$ and $10000 \mathrm{mg} / \mathrm{L})$ for the two types of cuttings (young and lignified) obtained from the top, crown and base of Calophyllum brasiliense and the coefficient of determination $\left(R^{2}\right)$.

Tabela 3 Porcenta de sobrevivência, enraizamento, brotação e calo de crescimento (tratamentos de I a 30) com cinco doses de ácido indolbutilico (AIB) testado $\left(0,100,6000,5000,10000 \mathrm{mg} \cdot \mathrm{L}^{-1}\right)$ para os dois tipos de estacas (jovem e madura) obtida do topo, copa e base de Calophyllum brasiliense com coeficiente de determinação $\left(R^{2}\right)$.

\begin{tabular}{|c|c|c|c|c|c|c|c|}
\hline Treatment & Portion & Type & Dose (ppm) & Survivel & Rooting & Sproutin & Callus Formation \\
\hline 1 & Top & Lignified & 0 & $41,7 \%$ & $0,0 \%$ & $0,0 \%$ & $0,0 \%$ \\
\hline 2 & Top & Lignified & 100 & $16,7 \%$ & $0,0 \%$ & $8,3 \%$ & $0,0 \%$ \\
\hline 3 & Top & Lignified & 1000 & $58,3 \%$ & $0,0 \%$ & $25,0 \%$ & $41,7 \%$ \\
\hline 4 & Top & Lignified & 5000 & $50,0 \%$ & $0,0 \%$ & $16,7 \%$ & $0,0 \%$ \\
\hline 5 & Top & Lignified & 10000 & $66,7 \%$ & $8,3 \%$ & $41,7 \%$ & $25,0 \%$ \\
\hline $\mathrm{R}^{2}$ & Top & Lignified & - & 0,47 & 0,77 & 0,70 & 0,05 \\
\hline 6 & Top & Young & 0 & $75,0 \%$ & $0,0 \%$ & $0,0 \%$ & $16,7 \%$ \\
\hline 7 & Top & Young & 100 & $75,0 \%$ & $0,0 \%$ & $16,7 \%$ & $0,0 \%$ \\
\hline 8 & Top & Young & 1000 & $66,7 \%$ & $16,7 \%$ & $33,3 \%$ & $16,7 \%$ \\
\hline 9 & Top & Young & 5000 & $58,3 \%$ & $0,0 \%$ & $25,0 \%$ & $25,0 \%$ \\
\hline 10 & Top & Young & 10000 & $66,7 \%$ & $0,0 \%$ & $25,0 \%$ & $33,3 \%$ \\
\hline $\mathrm{R}^{2}$ & Top & Young & - & 0,32 & 0,08 & 0,16 & $0,7 I$ \\
\hline 11 & Crown & Lignified & 0 & $16,7 \%$ & $0,0 \%$ & $8,3 \%$ & $0,0 \%$ \\
\hline 12 & Crown & Lignified & 100 & $25,0 \%$ & $0,0 \%$ & $0,0 \%$ & $25,0 \%$ \\
\hline 13 & Crown & Lignified & 1000 & $25,0 \%$ & $8,3 \%$ & $16,7 \%$ & $8,3 \%$ \\
\hline 14 & Crown & Lignified & 5000 & $50,0 \%$ & $0,0 \%$ & $25,0 \%$ & $41,7 \%$ \\
\hline 15 & Crown & Lignified & 10000 & $25,0 \%$ & $8,3 \%$ & $16,7 \%$ & $16,7 \%$ \\
\hline $\mathrm{R}^{2}$ & Crown & Lignified & - & 0,11 & 0,23 & 0,33 & 0,11 \\
\hline 16 & Crown & Young & 0 & $83,3 \%$ & $0,0 \%$ & $0,0 \%$ & $8,3 \%$ \\
\hline 17 & Crown & Young & 100 & $100,0 \%$ & $0,0 \%$ & $0,0 \%$ & $25,0 \%$ \\
\hline 18 & Crown & Young & 1000 & $91,7 \%$ & $25,0 \%$ & $8,3 \%$ & $25,0 \%$ \\
\hline 19 & Crown & Young & 5000 & $91,7 \%$ & $8,3 \%$ & $8,3 \%$ & $25,0 \%$ \\
\hline 20 & Crown & Young & 10000 & $91,7 \%$ & $8,3 \%$ & $8,3 \%$ & $8,3 \%$ \\
\hline $\mathrm{R}^{2}$ & Crown & Young & - & 0,00 & 0,01 & 0,45 & 0,14 \\
\hline 21 & Tree Base & Lignified & 0 & $8,3 \%$ & $0,0 \%$ & $8,3 \%$ & $0,0 \%$ \\
\hline 22 & Tree Base & Lignified & 100 & $33,3 \%$ & $8,3 \%$ & $33,3 \%$ & $16,7 \%$ \\
\hline 23 & Tree Base & Lignified & 1000 & $58,3 \%$ & $25,0 \%$ & $41,7 \%$ & $16,7 \%$ \\
\hline 24 & Tree Base & Lignified & 5000 & $33,3 \%$ & $16,7 \%$ & $25,0 \%$ & $16,7 \%$ \\
\hline 25 & Tree Base & Lignified & 10000 & $91,7 \%$ & $66,7 \%$ & $83,3 \%$ & $16,7 \%$ \\
\hline$R^{2}$ & Tree Base & Lignified & - & 0,60 & 0,80 & 0,64 & 0,17 \\
\hline 26 & Tree Base & Young & 0 & $91,7 \%$ & $8,3 \%$ & $8,3 \%$ & $0,0 \%$ \\
\hline 27 & Tree Base & Young & 100 & $91,7 \%$ & $33,3 \%$ & $33,3 \%$ & $16,7 \%$ \\
\hline 28 & Tree Base & Young & 1000 & $100,0 \%$ & $83,3 \%$ & $66,7 \%$ & $0,0 \%$ \\
\hline 29 & Tree Base & Young & 5000 & $58,3 \%$ & $33,3 \%$ & $25,0 \%$ & $0,0 \%$ \\
\hline 30 & Tree Base & Young & 10000 & $66,7 \%$ & $8,3 \%$ & $0,0 \%$ & $16,7 \%$ \\
\hline $\mathrm{R}^{2}$ & Tree Base & Young & - & 0,63 & 0,14 & 0,27 & 0,15 \\
\hline
\end{tabular}


Table 4 Analysis of variance (ANOVA) of the parameters assessed (survival, rooting, sprouting and callus growth) in cuttings of Calophyllum brasiliense Cambess.

Tabela 4 Análise de variancia (ANOVA) dos parametros avaliados (sobrevivência) enraizamento, brotação e crescimento de calo) em brotos Calophyllum brasiliense Cambess.

\begin{tabular}{|c|c|c|c|c|}
\hline $\begin{array}{l}\text { Variation } \\
\text { Source }\end{array}$ & Survivel & Rooting & Sprouting & $\begin{array}{c}\text { Callus } \\
\text { Formation }\end{array}$ \\
\hline & \multicolumn{4}{|c|}{ Value f (significance) } \\
\hline Treatment & 0,0000 & 0,0000 & 0,0015 & 0,5069 \\
\hline Repetition & 0,1219 & $0,374 I$ & 0,1219 & $0,047 \mid$ \\
\hline $\mathrm{CV}$ & 19,23 & 18,17 & 31,43 & 27,25 \\
\hline I & $\mathrm{I}, 33 \mathrm{a}$ & $\mathrm{I}, 00 \mathrm{a}$ & $\mathrm{I}, 00 \mathrm{a}$ & $\mathrm{I}, 00 \mathrm{a}$ \\
\hline 2 & $\mathrm{I}, 00 \mathrm{a}$ & $\mathrm{I}, 00 \mathrm{a}$ & $1,00 \mathrm{a}$ & $2,00 \mathrm{a}$ \\
\hline 3 & $2,00 \mathrm{a}$ & $1,00 \mathrm{a}$ & $1,00 \mathrm{a}$ & $1,67 \mathrm{a}$ \\
\hline 4 & $1,67 \mathrm{a}$ & $1,00 \mathrm{a}$ & $1,00 \mathrm{a}$ & $1,00 \mathrm{a}$ \\
\hline 5 & $1,67 \mathrm{a}$ & $1,00 \mathrm{a}$ & $1,67 \mathrm{a}$ & $1,00 \mathrm{a}$ \\
\hline 6 & $2,00 \mathrm{a}$ & $1,00 \mathrm{a}$ & $1,00 \mathrm{a}$ & $1,33 \mathrm{a}$ \\
\hline 7 & $2,00 \mathrm{a}$ & $\mathrm{I}, 00 \mathrm{a}$ & $\mathrm{I}, 00 \mathrm{a}$ & $\mathrm{I}, 00 \mathrm{a}$ \\
\hline 8 & $2,00 \mathrm{a}$ & $1,00 \mathrm{a}$ & $1,67 \mathrm{a}$ & $1,33 \mathrm{a}$ \\
\hline 9 & $1,67 \mathrm{a}$ & $1,00 \mathrm{a}$ & $1,33 \mathrm{a}$ & $1,33 \mathrm{a}$ \\
\hline 10 & $2,00 \mathrm{a}$ & $\mathrm{I}, 00 \mathrm{a}$ & $1,67 \mathrm{a}$ & $\mathrm{I}, 33 \mathrm{a}$ \\
\hline 11 & $1,00 \mathrm{a}$ & $\mathrm{I}, 00 \mathrm{a}$ & $1,00 \mathrm{a}$ & $\mathrm{I}, 00 \mathrm{a}$ \\
\hline 12 & $\mathrm{I}, 33 \mathrm{a}$ & $\mathrm{I}, 00 \mathrm{a}$ & $1,00 \mathrm{a}$ & $\mathrm{I}, 33 \mathrm{a}$ \\
\hline 13 & $1,00 \mathrm{a}$ & $1,00 \mathrm{a}$ & $1,00 \mathrm{a}$ & $\mathrm{I}, 00 \mathrm{a}$ \\
\hline 14 & $1,67 \mathrm{a}$ & $\mathrm{I}, 00 \mathrm{a}$ & $\mathrm{I}, 33 \mathrm{a}$ & $\mathrm{I}, 67 \mathrm{a}$ \\
\hline 15 & $1,33 \mathrm{a}$ & $\mathrm{I}, 00 \mathrm{a}$ & $\mathrm{I}, 00 \mathrm{a}$ & $\mathrm{I}, 33 \mathrm{a}$ \\
\hline 16 & $2,00 \mathrm{a}$ & $\mathrm{I}, 00 \mathrm{a}$ & $1,00 \mathrm{a}$ & $\mathrm{I}, 00 \mathrm{a}$ \\
\hline 17 & $2,00 \mathrm{a}$ & $\mathrm{I}, 00 \mathrm{a}$ & $\mathrm{I}, 00 \mathrm{a}$ & $\mathrm{I}, 33 \mathrm{a}$ \\
\hline 18 & $2,00 \mathrm{a}$ & I,33 ab & $\mathrm{I}, 00 \mathrm{a}$ & $\mathrm{I}, 33 \mathrm{a}$ \\
\hline 19 & $2,00 \mathrm{a}$ & $\mathrm{I}, 00 \mathrm{a}$ & $1,00 \mathrm{a}$ & $\mathrm{I}, 33 \mathrm{a}$ \\
\hline 20 & $2,00 \mathrm{a}$ & $1,00 \mathrm{a}$ & $1,00 \mathrm{a}$ & $1,00 \mathrm{a}$ \\
\hline 21 & $1,00 \mathrm{a}$ & $1,00 \mathrm{a}$ & $1,00 \mathrm{a}$ & $\mathrm{I}, 00 \mathrm{a}$ \\
\hline 22 & $\mathrm{I}, 33 \mathrm{a}$ & $1,00 \mathrm{a}$ & $\mathrm{I}, 33 \mathrm{a}$ & $\mathrm{I}, 33 \mathrm{a}$ \\
\hline 23 & $1,67 \mathrm{a}$ & I,33 ab & $\mathrm{I}, 33 \mathrm{a}$ & $\mathrm{I}, 33 \mathrm{a}$ \\
\hline 24 & $\mathrm{I}, 33 \mathrm{a}$ & $\mathrm{I}, 00 \mathrm{a}$ & $1,33 \mathrm{a}$ & $\mathrm{I}, 00 \mathrm{a}$ \\
\hline 25 & $2,00 \mathrm{a}$ & $2,00 \mathrm{~b}$ & $2,00 \mathrm{a}$ & $\mathrm{I}, 00 \mathrm{a}$ \\
\hline 26 & $2,00 \mathrm{a}$ & $\mathrm{I}, 00 \mathrm{a}$ & $\mathrm{I}, 00 \mathrm{a}$ & $\mathrm{I}, 00 \mathrm{a}$ \\
\hline 27 & $2,00 \mathrm{a}$ & I,33ab & $\mathrm{I}, 33 \mathrm{a}$ & $\mathrm{I}, 00 \mathrm{a}$ \\
\hline 28 & $2,00 \mathrm{a}$ & $2,00 \mathrm{~b}$ & $2,00 \mathrm{a}$ & $\mathrm{I}, 00 \mathrm{a}$ \\
\hline 29 & $2,00 \mathrm{a}$ & I,33 ab & $1,33 \mathrm{a}$ & $1,00 \mathrm{a}$ \\
\hline 30 & $2,00 a$ & $1,00 \mathrm{a}$ & $1,00 \mathrm{a}$ & $1,00 \mathrm{a}$ \\
\hline
\end{tabular}

higher survival, rooting and sprouting. Only callus growth rate was lower for young or lignified cuttings.

When treatments are analyzed separately, lignified cuttings, presents the best results in the highest concentration of IBA tested (10000 mg. $\left.\mathrm{L}^{-1}\right)$. Best results for young cuttings were in the intermediate concentrations of IBA (1000 and $\left.5000 \mathrm{mg} \cdot \mathrm{L}^{-1}\right)$, as shown in Table 3.

The treatments with the best performances were for cuttings from the base of the trees, both young and lignified, in the IBA concentrations of 1000 and $10000 \mathrm{mg} \cdot \mathrm{L}^{-1}$, respectively.

Lignified cuttings achieved higher capacity of sprouting, lignified cuttings presented best rooting results with higher IBA doses. Xavier et al. (2009) related gains from growing regulators applications in materials with more difficult rooting, or for genetic questions, or in function of the cuttings maturity. It could explain the best rooting for lignified cuttings observed in the higher IBA doses.

Davis et al. (1986) relates that young sprouts generally present lower lignification, which gets higher from the top to the base of the branches, where the tissue presents a higher grade of differentiation, with lower capacity to recover the meristem conditions, fundamental to start rooting, due to it the young cutting obtained a higher level of rooting. The low rate of rooting observed in the mature material from the planted trees tested confirm this affirmation, and when compared with $85 \%$ of average rooting achieved with cuttings of Calophyllum brasiliense of young material achieved by Silva et al (20I0).

\section{Second rooting trial}

The second trial aimed at verifying the best performance of cuttings from the tree base, which presented the best results in the first trial. This trial also tested cuttings from seedlings, a younger material with higher probability of rooting, and reduced the interval between the IBA concentrations (inclusion of 3.000 and $7.000 \mathrm{mg} \cdot \mathrm{L}^{-1}$ ). Trial evaluation was carried out after 120 days of experiment, removing the cuttings from the tubes.

Cuttings from seedlings presented better results in comparison to cuttings from trees, which demonstrate higher survival and rooting of the young material (Table 5). Roots were not scanned to evaluate the quantity and quality, but visually cuttings from seedlings presented larger volume of roots, as well as faster rooting.

As shown in Table 5, the introduction of two more test-concentrations of IBA (3000 and 7000 $\left.\mathrm{mg} \cdot \mathrm{L}^{-1}\right)$ demonstrated the importance of reducing the 
Table 5 Percentages of survival, rooting, sprouting and callus formation according to cutting provenance and concentrations of indole-butyric acid (IBA) concentrations (0, 100, 1000, 3000, 5000, 7000 and $10000 \mathrm{mg} \cdot \mathrm{L}^{-1}$ ) for Calophyllum brasiliense.

Tabela 5 Porcetagem de sobrevivência, enraizamento, brotação e formação de calo, de acordo com a origem da estação e concentração de (AIB) (0, 100, 1000, 3000, 5000, 7000 and 10000 mg. $\left.\mathrm{L}^{-1}\right)$ para Calophyllum brasiliense.

\begin{tabular}{ccccccc}
\hline Treatment & Stump Provenance & Dose IBA $(\mathrm{ppm})$ & Survivel & Rooting & Sprouting & Callus Formation \\
\hline I & Tree Base & 0 & $75,0 \%$ & $35,0 \%$ & $5,0 \%$ & $0,0 \%$ \\
2 & Tree Base & 100 & $75,0 \%$ & $20,0 \%$ & $30,0 \%$ & $10,0 \%$ \\
3 & Tree Base & 1000 & $60,0 \%$ & $15,0 \%$ & $15,0 \%$ & $5,0 \%$ \\
4 & Tree Base & 3000 & $75,0 \%$ & $75,0 \%$ & $0,0 \%$ & $5,0 \%$ \\
5 & Tree Base & 5000 & $55,0 \%$ & $20,0 \%$ & $10,0 \%$ & $5,0 \%$ \\
6 & Tree Base & 7000 & $65,0 \%$ & $35,0 \%$ & $5,0 \%$ & $10,0 \%$ \\
7 & Tree Base & 10000 & $75,0 \%$ & $25,0 \%$ & $30,0 \%$ & $5,0 \%$ \\
\hline$R^{2}$ & Tree Base & - & 0,01 & 0,00 & 0,03 & 0,05 \\
\hline 8 & Seedling Top & 0 & $85,0 \%$ & $50,0 \%$ & $20,0 \%$ & $5,0 \%$ \\
9 & Seedling Top & 100 & $100,0 \%$ & $20,0 \%$ & $45,0 \%$ & $10,0 \%$ \\
I0 & Seedling Top & 1000 & $85,0 \%$ & $15,0 \%$ & $30,0 \%$ & $10,0 \%$ \\
II & Seedling Top & 3000 & $90,0 \%$ & $90,0 \%$ & $0,0 \%$ & $15,0 \%$ \\
I2 & Seedling Top & 5000 & $95,0 \%$ & $85,0 \%$ & $5,0 \%$ & $10,0 \%$ \\
I3 & Seedling Top & 7000 & $95,0 \%$ & $90,0 \%$ & $0,0 \%$ & $0,0 \%$ \\
I4 & Seedling Top & 10000 & $90,0 \%$ & $70,0 \%$ & $15,0 \%$ & $20,0 \%$ \\
\hline$R^{2}$ & Seedling Top & - & 0,02 & 0,42 & 0,33 & 0,09 \\
\hline
\end{tabular}

interval between the concentrations tested in the first trial, as the IBA $3000 \mathrm{mg} \cdot \mathrm{L}^{-1}$ presented the best results for the two types of cuttings.

Survival and sprouting did not show significant differences between treatments (ANOVA; p>0.05), whereas rooting and callus formation presented significant differences $(p<0.05$, Table 6).
High incidence of fungi diseases in the cuttings from the trees was noted, which caused lower survival, when compared to cuttings from seedlings. No fungicide was used throughout the experiment.

The best results for cuttings from trees and from seedlings were with treatments 4 and II, respectively. Control plants also presented good survival and rooting

Table 6 Analysis of variance (ANOVA) of the parameters assessed (survival, rooting, sprouting and callus growth) in cuttings of Calophyllum brasiliense.

Tabela 6 Análise de variância (ANOVA) dos parametros avaliados (sobrevivência, enraizamento, brotação e crescimento de calo em brotos de Calophyllum brasiliense.

\begin{tabular}{lllll}
\hline Variation Source & Survivel & Rooting & Callus Formation & Sprouting \\
\hline Treatment & & \multicolumn{2}{c}{ Value de f (significance) } & 0,7043 \\
Repetition & 0,0408 & 0,0000 & 0,0000 & 0,9807 \\
CV & $0,57 \mathrm{I} 2$ & 0,9276 & 0,8048 & 160,10 \\
\hline $\mathrm{I}$ & 23,90 & 37,38 & 80,29 & $0,00 \mathrm{a}$ \\
2 & $3,75 \mathrm{a}$ & $1,75 \mathrm{bc}$ & $0,25 \mathrm{~b}$ & $0,50 \mathrm{a}$ \\
3 & $3,75 \mathrm{a}$ & $1,00 \mathrm{c}$ & $1,50 \mathrm{ab}$ & $0,25 \mathrm{a}$ \\
4 & $3,25 \mathrm{a}$ & $0,75 \mathrm{c}$ & $0,25 \mathrm{a}$ \\
5 & $3,75 \mathrm{a}$ & $3,75 \mathrm{ab}$ & $0,75 \mathrm{ab}$ & $0,25 \mathrm{a}$ \\
6 & $2,75 \mathrm{a}$ & $1,00 \mathrm{c}$ & $0,50 \mathrm{a}$ \\
7 & $3,75 \mathrm{a}$ & $1,75 \mathrm{bc}$ & $0,00 \mathrm{~b}$ & $0,25 \mathrm{a}$ \\
8 & $3,75 \mathrm{a}$ & $1,25 \mathrm{c}$ & $0,50 \mathrm{~b}$ & $0,25 \mathrm{a}$ \\
9 & $4,25 \mathrm{a}$ & $2,50 \mathrm{abc}$ & $1,50 \mathrm{ab}$ & $0,50 \mathrm{a}$ \\
10 & $5,00 \mathrm{a}$ & $1,00 \mathrm{c}$ & $1,00 \mathrm{ab}$ & $0,50 \mathrm{a}$ \\
$1 \mathrm{I}$ & $4,25 \mathrm{a}$ & $0,75 \mathrm{c}$ & $2,25 \mathrm{a}$ & $0,75 \mathrm{a}$ \\
12 & $4,50 \mathrm{a}$ & $4,50 \mathrm{a}$ & $1,50 \mathrm{ab}$ & $0,50 \mathrm{a}$ \\
13 & $4,75 \mathrm{a}$ & $4,25 \mathrm{a}$ & $0,00 \mathrm{~b}$ & $0,00 \mathrm{a}$ \\
14 & $4,75 \mathrm{a}$ & $4,50 \mathrm{a}$ & $0,25 \mathrm{~b}$ & $0,75 \mathrm{a}$ \\
\hline
\end{tabular}

*CV: Coefficient of variation; Tukey test at $5 \%$ de probability 
rates, which revealed that the species has potential for natural vegetative propagation, and potential to rooting without use of IBA, as observed by Silva et al (20I0). Santos (2002) affirms that there is a maximum level for IBA application that is prejudicial, ascan be observed in the rooting results for the $10.000 \mathrm{mg} \cdot \mathrm{L}^{-1}$ (14 treatment) doses of IBA when rooting starts decresing.

\section{CONCLUSIONS}

Calophyllum brasiliense is a feasible species for vegetative propagation through cutting technique and may be widely used in the mass production of improved material. Young cuttings from the base of the trees presented best results for mature material, and the best concentration of indole-butyric acid (IBA) was 3000 $\mathrm{mg} \cdot \mathrm{L}^{-1}$, with $75 \%$ rooting. Rooting of young material presented the best results, demonstrating good potential for the establishment of clonal plantations.

\section{ACKNOWLEDGEMENTS}

Dr. Edson Seizo Mori for all support, guidance and patiente, and the Tropical Flora Reflorestadora Ltda. for the incentive, opotunity and support to do my Masters along with my professional activities in the company.

\section{REFERENCES}

ASSOCIAÇÃO BRASILEIRA DA INDÚSTRIA DE MADEIRA
PROCESSADA MECANICAMENTE. setorial 2008 indústria de madeira processada mecanicamente. Curitiba, 2008. 56 p.

CARPANEZZI, A. A. Benefícios indiretos da floresta. In: GALVÃO, A. P. M. (Ed.) Reflorestamento de propriedades rurais para fins produtivos e ambientais: um guia para ações municipais e regionais. Brasília, DF: Embrapa Floresta, 2000. cap. 2, p. 19-55.

DAVIS T.D., HAISSIG B.E., SANKHLA N. 1986. Adventitious root formation in cuttings. Oregon: Dioscorides Press, 315 p.
FERREIRA, C. A.; GALVÃO, A. P. M. Importância da atividade florestal no Brasil: In: GALVÃO, A. P. M. (Ed.). Reflorestamento de propriedades rurais para fins produtivos e ambientais: um guia para ações municipais e regionais. Brasília, DF: Embrapa Floresta, 2000. v. I, p. 15-18.

FERREIRA, D. F. Software de análise estatística Sisvar. versão 4. 2. Lavras: Universidade Federal de Lavras, 2003. I CD-ROM.

KALIL FILHO, A. N.; WENDLING, I.; FRANCISCON, L. Propagação vegetativa do guanandi por miniestaquia. Embrapa Florestas: Colombo - PR, 20I0, 4p.

MORA, A. L.; GARCIA, C. H. Eucalypt cultivation in Brazil. São Paulo: Sociedade Brasileira de Silvicultura, 2000. I I 2p.

PIMENTEL-GOMES, F. P. Curso de estatística experimental. 8. ed. São Paulo: Nobel, 1978. 430 p.

PIOTTO, D. et al. Growth and effects of thinning of mixed and pure plantations with native trees in humid tropical Costa Rica. Forest Ecology and Management, Cambridge, v. I77, n. I-3, p. 427-439, 2003 a.

PIOTTO, D. et al. Performance of forest plantations in small and medium-sized farms in the Atlantic lowlands of Costa Rica. Forest Ecology and Management, Cambridge, v. I75, n. I-3, p. 195-204, 2003b.

SANTOS G. 2002. Miniestaquia na clonagem de jequitibá, mogno, cedro e canjerana. 70 f. Monografia (Graduação)Universidade Federal de Viçosa, Viçosa.

SILVA, R. L.; OLIVEIRA, M. L.; MONTE, M. A.; XAVIER, A. Propagação clonal de guanandi (Calophyllum brasiliense) por miniestaquia. Agronomía Costarricense 34(I): 99-104. 2010.

TZFIRA, T. et. al. Forest-tree biotecnology: genetic transformation and its application to future forests. Trends in Biotechnology, Cambridge, v. 16, p. 439-446, 1998.

XAVIER A., WENDLING I., SILVA R.L. 2009. Silvicultura clonal: princípios e técnicas. Viçosa, MG: UFV. 276 p.

XAVIER A., SANTOS A., WENDLING I., OLIVEIRA M.L. 2003. Propagação vegetativa de Cedro-rosa por miniestaquia. Revista Árvore, 27(2):139-143. 
